УДК 37.018.43.016:82(100)

Гарна Світлана Юріївна

завідувач відділу гуманітарної освіти, старший викладач кафедри історії,

суспільно-гуманітарних дисциплін та методики їх викладання

Донецький обласний інститут післядипломної педагогічної освіти, м. Донецьк, Україна

ORCID ID 0000-0003-1254-9044

garnasveta@ukr.net

\title{
ОРГАНІЗАЦІЯ УРОКУ ЗАРУБІЖНОЇ ЛІТЕРАТУРИ В СИСТЕМІ ДИСТАНЦЙНОГО НАВЧАННЯ ШКОЛЯРІВ
}

\begin{abstract}
Анотація. У статті здійснено огляд останніх педагогічних і науково-методичних праць у контексті проблеми організації дистанційної літературної освіти сучасних учнів, визначено методологічну базу для розробки в подальшому методичної системи використання технологій дистанційного навчання у процесі вивчення зарубіжної літератури старшокласниками. Проведено моніторинг структури, змісту й методичного інструментарію електронного уроку із зарубіжної літератури в системі дистанційної освіти Донеччини для старшокласників з окупованих територій, вивчено переваги й недоліки такого формату навчального діалогу між педагогом-куратором і учнем. Запропоновано авторське бачення організації заняття 3 віддаленим доступом, надано рекомендації щодо побудови i проведення ефективного електронного уроку, розширено палітру дидактичного інструментарію сучасного учителя-словесника 3 урахуванням специфіки дистанційного навчання.
\end{abstract}

Ключові слова: дистанційна освіта; дистанційне навчання; літературна освіта; електронний урок; методичний інструментарій; кейси матеріалів із зарубіжної літератури.

\section{1. ВСТУП}

Постановка проблеми. Сучасні соціально-економічні, політичні, культурні перетворення на перший план висувають проблему модернізації змісту освіти, пошуку нових освітніх парадигм, зорієнтованих не так на отримання певної бази знань, як на здатність особистості до навчання протягом усього життя.

Дослідники переконані, що досягнення інформаційних технологій дозволяють розв'язати зазначену проблему шляхом широкого застосування у сфері освіти дистанційного навчання (П. Камінська, Ю. Новіков, В. Томашевський та ін.). У наукових педагогічних колах також сформульоване бачення, що основна ідея оновлення старшої ланки загальної освіти полягає в необхідності іiі переосмислити 3 урахуванням критеріїв індивідуалізації, функціональності й ефективності. Тому необхідно організувати навчальний процес у старших класах так, щоб учні мали можливість більшою мірою задовольнити свої запити, краще підготуватися до здобуття професійної освіти в подальшому, усвідомити, наскільки правильно зроблений вибір. Саме тому важливо особливо ретельно підходити до розробки теоретичних основ дистанційного навчання школярів.

Актуальність дослідження зумовлена необхідністю вдосконалити зміст дистанційного навчання в сучасній школі, ураховуючи реальний стан проблеми, адаптувати традиційний методичний інструментарій до нових умов i розробити специфічний, а також, у нашому випадку, потребою зорганізувати якісний процес навчання 3 віддаленим доступом учнів 3 тимчасово непідконтрольних територій та забезпечити реалізацію їх права як громадян України на здобуття освіти. 
Зв'язок авторського доробку 3 важливими науковими i практичними завданнями полягає в тому, що відповідно до Концепції розвитку дистанційної освіти України передбачено забезпечення розвитку освіти на основі прогресивних ідей, запровадження в навчально-виховний процес інноваційних педагогічних технологій i науково-методичних досягнень, створення нової системи інформаційного забезпечення освіти, входження України у трансконтинентальну систему комп'ютерної інформації [1]. У статті ми на прикладі вивчення зарубіжної літератури окреслюємо основні проблеми, з якими стикаються загальноосвітні навчальні заклади в процесі реалізації цих положень.

Аналіз останніх досліджень і публікацій свідчить про значну увагу до проблем упровадження дистанційних технологій у навчальний процес. Науково-педагогічні засади дистанційного навчання розробляли вітчизняні вчені Ю. Богачков, В. Гриценко, В. Кухаренко, В. Олійник, В. Рибалко, Н. Сиротенко, П. Стефаненко та ін. Окремі аспекти проблеми щодо змісту й організації навчання 3 віддаленим доступом висвітлено в працях М. Бесєдіної, Є. Блінова, К. Власенко, В. Гура, Н. Дацун, М. Ус та ін. Суттєвий інтерес для нашого дослідження також становлять пошуки зарубіжних науковців (О. Андреєв, Р. Бел, Дж. Блумстук, Д. Кіган, Дж. Коумі, М. Моїсєєва, Є. Полат, В. Солдаткін, А. Хуторськой та ін.).

У розвідках з української й зарубіжної методик вивчення шкільного курсу літератури сучасні дослідники так чи так наблизились до розв'язання означеної проблеми загалом і намітили перспективи подальших пошуків. У нашому полі зору праці О. Александрової (екранне читання як один із прийомів формування компетентнісного читача); А. Богосвятської, С. Гарної, Ю. Еельмаа, С. Федорова (інформаційно-комунікаційні технології в літературній освіті школярів); Н. Волошиної (перспективні педагогічні технології і новаторські форми занять у практиці вчителя літератури), О. Дем'яненко (використання елементів медіаосвіти у вивченні літератури школярами); С. Жили (роль суміжних видів мистецтв у сприйманні учнями літературних текстів); В. Журавльова (аудіальний аспект «прочитання» художнього твору на уроці літератури); О. Ісаєвої (специфіка читацької діяльності школярів із залученням у освітнє середовище медіатекстів і креолізованих текстів, явище піарменеджменту в діяльності вчителя-словесника, навчання літератури в цифрову епоху); Ж. Клименко (засоби і форми оцінювання навчальних досягнень учнів 3 літератури); Л. Мірошниченко, Ц. Палмер (загальна проблематика використання комп'ютерних технологій у літературній освіті школярів); І. Ціка (медіадидактичні засади навчання літератури в школі); В. Шуляра (електронне конструювання уроку літератури) та ін. [214]. I, хоча висвітлені питання безпосередньо не стосуються аспектів нашої розвідки, вони дозволяють окреслити інноваційне поле діяльності сучасного вчителя й учнячитача та в подальшому стануть підгрунтям для розробки моделі методичної системи щодо використання технологій дистанційного навчання в процесі вивчення зарубіжної літератури старшокласниками.

Отже, зважаючи на наявність різнопланових і досить масштабних наукових пошуків із залученням інноваційного освітнього середовища, нині практично відсутні напрацювання, у яких би цілісно й усебічно розглядалася саме проблема методики використання технологій дистанційного навчання в процесі вивчення зарубіжної літератури в загальноосвітніх навчальних закладах. Так, сучасна дистанційна освіта в Україні нагадує традиційні форми заочного навчання, не розкриваючи всіх можливостей використання принципово нових форм і методів навчання.

Тому мета статті - проаналізувати зміст електронного уроку із зарубіжної літератури, його навчально-методичне наповнення на основі матеріалів платформи «Еschool. Дистанційне навчання в школі» та, відповідно, відкоригувати структуру такого 
заняття. Надати рекомендації педагогам-кураторам, які супроводжують процес віддаленого доступу до навчального матеріалу учнів-читачів з окупованих територій.

\section{2. МЕТОДИ ДОСЛІДЖЕННЯ}

У статті було використано комплекс методів дослідження: теоретичні - методи аналізу й синтезу, обробки й інтерпретації джерел спрямовано на вивчення науковометодичних праць за проблемою дослідження, нормативної бази в галузі освіти; емпіричні - спостереження за навчальним процесом, методи діагностування стали основою для визначення стану елементів дистанційного навчання в школах Донеччини.

\section{3. РЕЗУЛЬТАТИ ДОСЛІДЖЕННЯ}

Однією із суттєвих ознак модернізації сучасної школи $є$ впровадження дистанційного навчання, що значно розширює інформаційні межі навчального змісту окремого предмета й програмової теми, підвищує якість освітніх послуг.

Згідно 3 відповідним Положенням дистанційне навчання визначається як «індивідуалізований процес набуття знань, умінь, навичок і способів пізнавальної діяльності людини, що відбувається в основному за опосередкованої взаємодії віддалених один від одного учасників навчального процесу в спеціалізованому середовищі, яке функціонує на базі сучасних психолого-педагогічних та інформаційнокомунікаційних технологій» [15]. Про нагальність упровадження дистанційного формату як альтернативного на завершальних щаблях повної базової середньої освіти йдеться в Концептуальних засадах реформування середньої освіти «Нова українська школа». У згаданому документі наголошується на необхідності розвитку інфраструктури «для забезпечення різних форм навчання», зокрема створення освітньої онлайн платформи «з навчальними і методичними матеріалами для учнів, учителів, батьків і керівників навчальних закладів» [16].

Мета такого навчання - надання освітніх послуг шляхом застосування сучасних інформаційно-комунікаційних технологій за певними освітніми чи освітньокваліфікаційними рівнями відповідно до державних стандартів освіти.

Дистанційна освіта - це нова форма організації навчального процесу, що базується на принципах самостійної діяльності школярів. Середовище такого навчання характеризується тим, що часто учні з різних причин (маючи обмежені фізичні можливості за станом здоров'я, перебуваючи 3 родиною на окупованих територіях, навчаючись за індивідуальним графіком під час підготовки до інтелектуальних чи спортивних змагань тощо) віддалені від учителя в просторі або часі, проте мають можливість у будь-яку хвилину підтримувати зв'язок із педагогом, користуючись досягненнями сучасних інформаційних технологій.

Дистанційне навчання має переваги, бо надає доступ до освітніх ресурсів усім, хто обрав такий шлях самовдосконалення, збільшує можливості традиційної очної освіти завдяки інформатизації освітнього середовища, у якому учень самостійно і під керівництвом учителя може вивчати необхідний матеріал, розширює можливість доступу до навчальних ресурсів, має велике соціальне значення, адже дає можливість задовольнити в повному обсязі освітні потреби населення.

На сайті Донецького обласного інституту післядипломної педагогічної освіти розгорнута платформа «E-school. Дистанційне навчання в школі» [17]. Вона створена для батьків, учителів і учнів та містить нормативну базу, рекомендації, зворотний зв'язок.

31 вересня 2016-2017 н. р., відповідно до наказу Департаменту освіти і науки Донецької облдержадміністрації, в області почали функціонувати п’ять базових 
дистанційних шкіл у мм. Бахмут, Краматорськ, Маріуполь, Покровськ, Слов’янськ. У них навчаються учні з тимчасово окупованих територій Донеччини.

Відзначимо головні переваги дистанційної форми навчання на платформі:

- доступність;

- індивідуальний процес навчання;

- розширення і багаторівневість знань з урахуванням можливостей використання сучасних Інтернет-технологій;

- удосконалення професійного рівня вчителів, які впроваджують інформаційні технології в навчальний процес;

- демократизація й універсалізація начального діалогу на основі взаємодії усіх учасників освітнього простору «педагог-куратор $\leftrightarrow$ учень $\leftrightarrow$ батьки»;

- упровадження провідних освітніх технологій.

Серед недоліків дистанційної форми навчання, за умов, що склалися, варто виділити такі:

- учні з непідконтрольних територій, навчаючись у двох загальноосвітніх навчальних закладах одночасно, майже не працюють 3 теоретичними матеріалами дистанційних курсів;

- ускладнена ідентифікація віддалених учнів, так як така модель дистанційного зв'язку обмежує педагога-куратора у відслідковуванні процесу навчальної діяльності та іiі результативності;

- недостатній рівень безпосереднього контакту між учнем і педагогом-куратором через професійну завантаженість останнього;

- потреба в стандартизації й уніфікації вимог до навчальних матеріалів, необхідних для реалізації на високому рівні мети й завдань дистанційного навчання;

- невисока якість навчально-методичних матеріалів i їх дидактичного потенціалу.

Під час моніторингу навчально-методичного забезпечення дистанційного навчання із зарубіжної літератури для учнів 9-11 класів 3'ясовано, що загалом структура дистанційних курсів $є$ такою: теоретичний матеріал (лекція), завдання до теми, додатки (мультимедійна презентація), контрольна робота (частіше - тестова) (рис. 1).

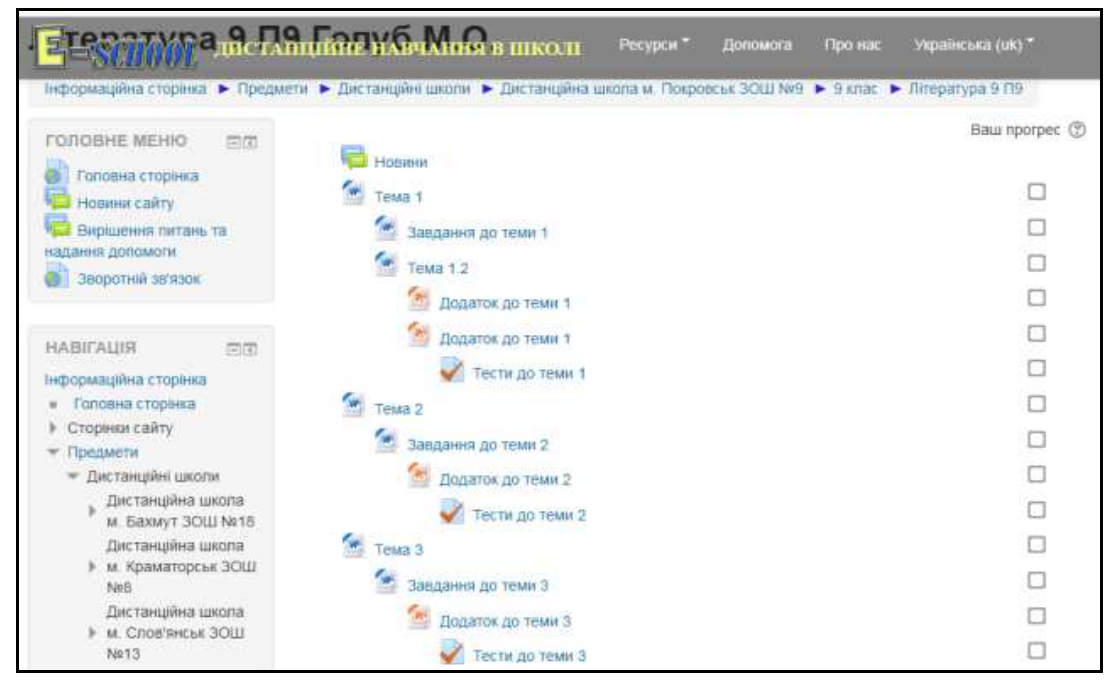

Рис. 1. Загальна структура дистаниійного курсу із зарубіжної літератури «E-school. Дистаниійне навчання в школі» 
Також нами виокремлено низку проблем, а саме: використання платформи педагогами неадаптованих для дистанційного навчання конспектів, недостатня кількість різнорівневих завдань, одноманітність видів контролю, відсутність належної мотивації й алгоритму дій для учнів. Отже, виявилося, що більшість педагогів не готові до роботи в дистанційному форматі.

Проаналізуємо детальніше деякі матеріали, надані як навчальний електронний контент для учнів старшої школи із зарубіжної літератури за вище означеною структурою.

Перший блок - виклад теоретичного матеріалу теми. Доводиться констатувати: педагоги-куратори, на жаль, часто використовують скановані варіанти конспектів уроків, де $\epsilon$, наприклад, вступне слово вчителя і картка з указівкою назви прийому навчання, власне запитанням і готовою відповіддю на нього (рис. 2), що є грубим порушенням методичної практики - учні не повинні чути (у даному випадку бачити) специфічну термінологію, якою оперує вчитель у професійній діяльності, помічати зміну етапів заняття, а зміст і характер подання теоретичних матеріалів має бути адаптованим для сприймання за умов віддаленого доступу.

\begin{tabular}{|c|c|}
\hline $\begin{array}{l}\text { 1. Вступне слово вчителя } \\
\text { - Філософи XVII ст. переконували: Бог подарував людині ро- } \\
\text { зум і серце. Людина повинна осягнути навколишній світ, такий } \\
\text { привабливий, загадковий і прекрасний, але при цьому вона повин- } \\
\text { на покладатися лише на себе. I людина захотіла зрозуміти закони } \\
\text { світобудови, покластися на власний досвід. В історії людства роз- } \\
\text { почалася нова доба, сповнена протиріч, суперечливих думок та по- } \\
\text { чуттів - бароко. }\end{array}$ & $\begin{array}{l}\text { 2. «Броунівський рух» } \\
\text { Картка № } 1 \\
\text { Що таке бароко? } \\
\text { Бароко (італ. barocco- дивний, химерний) - напрям у мисте- } \\
\text { цтві та літературі XVI-XVIII ст., якому належить важливе місце в } \\
\text { розвитку європейської культури. (Термін багатозначний, походить } \\
\text { від португальської назви la perrola baroca - перлина (або мушля } \\
\text { з перлиною) незвичайної форми.) Спочатку так назвали художній } \\
\text { стиль архітектури й образотворчого мистецтва XVII ст. Потім цей } \\
\text { термін поширили на музику й літературу. Сьогодні так називають }\end{array}$ \\
\hline
\end{tabular}

Рис. 2. Типове оформлення змісту першого блоку програмової теми дистаниійного курсу із зарубіжної літератури на платформі «E-school. Дистанційне навчання 8 школі»

Другий блок - завдання до теми. Спостерігаємо, наприклад, таке: педагогкуратор пропонує учням попрацювати в парах (?!) і сформулювати відповідь на запитання. Потім у дужках подається орієнтовне формулювання такої відповіді (рис. 3). Отже, прорахунки подібного гатунку очевидні: у площину дистанційної взаємодії автоматично переноситься методичний інструментарій очного формату навчання, який неможливо реалізувати за таких умов.

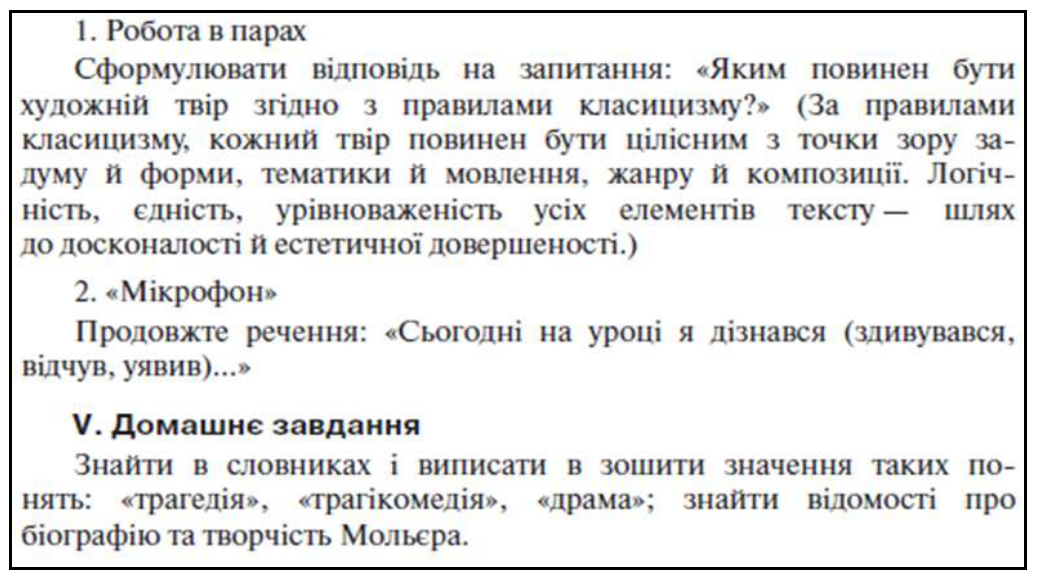

Рис. 3. Типове оформлення змісту другого блоку програмової теми дистаниійного курсу із зарубіжної літератури на платформі «Е-school. Дистанційне навчання в школі» 
Додаткові матеріали, які пропонує педагог-куратор, нерідко позбавлені дидактичного сенсу і слугують фоновим матеріалом, що можуть так чи так залишитися поза увагою учня чи недостатньо будуть опрацьовані. Також неприпустимим $є$ й те, що під жодним зображенням, ілюстрацією на слайдах навчального медіапродукту (у цьому випадку мультимедійної презентації) не спостерігаємо вихідної інформації (автор, назва мистецького твору, рік створення, коротка довідка-інформатор тощо).

Деякі матеріали мають суто інформативний характер і взагалі не передбачають зворотного зв'язку з учнем. Такий контент містить, наприклад, навчальний фільм про письменника (без запитань і завдань до нього), художній текст, його екранізацію, мультимедійну презентацію за твором та ін. Не передбачено вступної статті-звернення до учня, не розписано план його дій, немає чіткої системи різнорівневих завдань та різних форм поточного, проміжного й підсумкового контролю на підставі навчальних досягнень школярів (рис. 4).

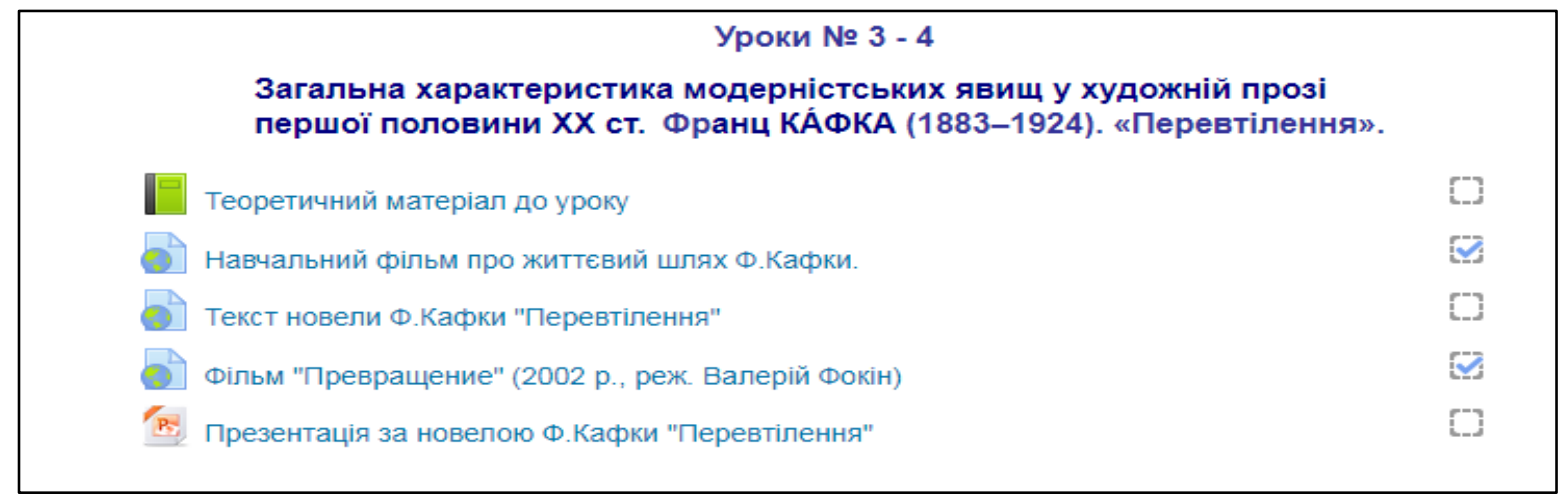

Рис. 4. Структура окремої програмової теми дистанційного курсу із зарубіжної літератури на платформі «E-school. Дистанщійне навчання в школі»

Так, до теми «Просвітництво як літературна епоха. Художні напрями доби. Ідейний зміст і художня структура філософської повісті «Простак», сенс ї̈ назви. Конфлікт «природної людини» $i$ франиузького суспільства. Антимонархічні та антиклерикальні мотиви твору» (9 клас) педагог-куратор пропонує такі завдання: «Опрацюйте за підручником параграфи 1-3 (стор. 67-84), вивчіть біографію Вольтера, прочитайте повість «Простак».

Наведені приклади свідчать про те, що є нагальна потреба у розробці контенту для дистанційного навчання учнів. Для цього була створена обласна творча група вчителів зарубіжної літератури під керівництвом завідувачки відділу гуманітарної освіти Донецького облІППО С. Ю. Гарної. Їі учасники долучились до формування кейсів матеріалів із зарубіжної літератури, що були розміщені на платформі «E-school. Дистанційне навчання в школі» у розділі для педагогів 3 можливістю їх завантаження й використання під час навчального процесу.

Наприклад, кейс за творчістю Е. Хемінгуея складається з таких матеріалів: текст про життєвий і творчий шлях письменника та літературний диктант для перевірки знань, документальний фільм про митця та завдання до нього, буктрейлер за повістюпритчею «Старий і море», сторінки підручника 3 текстом повісті-притчі «Старий і море» і критичний матеріал до неї, тестові завдання «Перевір себе» на знання змісту твору, уривок з екранізації твору й завдання до нього, система творчих завдань за повістю-притчею та різнорівнева контрольна робота за темою.

Учитель може на власний розсуд користуватися запропонованими матеріалами, готуючись до розробки уроків на відстані. При цьому необхідно пам'ятати, що таке 
заняття передбачає інакший формат діалогу вчителя й учня, оскільки їх розділяє час $\mathrm{i}$ простір. Тому важливо ретельно продумати структуру цього уроку й створити оптимальні умови для засвоєння навчального матеріалу.

Пропонуємо власне бачення проведення заняття на дистанції і рекомендації для педагогів-кураторів щодо підготовки матеріалів електронного уроку:

$\checkmark \mathrm{He}$ ототожнюйте матеріали дистанційного уроку 3 планом-конспектом, зазначаючи тип уроку, обладнання, мету (навчальну, розвивальну, виховну). Наголосіть на тому, що має засвоїти учень, які знання отримати та як їх застосувати. Наприклад, «На уроиі ти дізнаєшся ...», «Ми навчимося ...», «Ти маєш орієнтуватися ...», «Ти зможеш...».

$\checkmark$ Підготуйте невелике звернення-мотивацію до учня про важливість цієї теми (матеріалу).

Наприклад, урок за творчістю Й. В. Гете (9 клас) може розпочинатися таким зверненням учителя до учня:

Любий друже!

У будь-яку епоху філософи й письменники намагаються збагнути правду про природу людини і світ, щзо ї̈ оточуує, відкрити таємниці душі, пізнати істину буття. Відчути ц̌ знайти своє покликання, пізнати сутність добра та зла, відшукати відповіді на одвічні філософські питання прагнув Й. В. Гете - один із найвидатніших просвітників.

Справою всього життя письменника було створення унікальної й дивовижної книги, яка стала настільною для багатьох освічених людей. Звичайно, щзо ие драматична поема «Фауст». Й. В. Гете, за даними одних дослідників, прачював над грандіозним філософським твором понад 30 років, інших - близько 60 і завершив його незадовго до смерті. У тебе є чудова нагода розглянути шедевр світової літератури й відкрити важливі істини, які хвилюють не одне покоління.

Можливо, ия книга допоможе тобі відчути своє призначення й розкриє необхідність самопізнання. Бажаю тобі успіху!

$\checkmark$ Оберіть форму звертання до учня: ти або ви.

$\checkmark$ Не вказуйте етапи уроку. Увиразніть їх фразами типу: «Повторимо матеріал попереднього уроку», «Пригадай матеріал», «Підсумуємо прочитане», «Наголосимо на основних моментах» тощо.

$\checkmark$ Візьміть до уваги, що електронний урок може складатися з таких компонентів: текст, зображення (ілюстрації, репродукції картин), відео- та аудіоматеріали, різнорівневі завдання, тести, інтерактивні вправи, мультимедійні презентації, географічні мапи, схеми, сигнальні конспекти, інфографіка тощо.

$\checkmark$ Увесь матеріал е-уроку структуруйте на пункти й підпункти.

$\checkmark$ Пропонуйте учням різні види завдань чи елементи контролю на всіх етапах електронного уроку.

$\checkmark$ Пропонуючи завдання на відтворення фактичного матеріалу, робіть посилання на розділи (абзаци, частини), де він знаходиться. У разі труднощів це спонукає учня вкотре повернутися до теоретичного матеріалу чи тексту художнього твору.

$\checkmark$ Пам'ятайте загальні вимоги до оформлення е-контенту: 1) фон документа має бути світлий; 2) текст може бути маркованим не більше як трьома кольорами (основний - темними відтінками, заголовки й підзаголовки - відповідно до сумісної з основним текстом кольорової гами); 3) кегль шрифту для учнів 57 класів має складати 14 пунктів, учнів 8-11 класів - 12; 4) великі за обсягом зображення (географічні мапи, схеми тощо) доцільно завантажувати окремими файлами та пропонувати для перегляду за допомогою навігаційних кнопок. 
Додаткові матеріали (за наявності) подавайте у вигляді посилань або файлів для завантаження.

$\checkmark$ Якщо теоретичний чи практичний матеріал містить зображення (ілюстрацію, репродукцію картини, фото мистецької інсталяції тощо), обов'язково додайте інформаційну довідку потрібного змісту (від указівки автора й назви до цікавого, дотепного факту, пов'язаного із цим зображенням, враженням від нього визначної постаті або пересічної людини), використайте це зображення та матеріал інформаційної довідки у роботі з учнем.

$\checkmark$ Для перевірки знань учнів розробіть різнорівневі тести різних видів: з однією правильною відповіддю, 3 декількома правильними видами, 3 відкритою текстовою або цифровою відповіддю, на встановлення послідовності, відповідності тощо.

$\checkmark$ Якщо передбачено використання мультимедійних презентацій, урахуйте, що вони обов'язково мають містити коментарі до запропонованих матеріалів. Пам'ятайте: те, що вчитель коментує усно на звичайному уроці, у дистанційному форматі педагог-куратор здійснює засобами письма. Для цілісного сприймання навчального матеріалу зображення i його опис розміщуйте на одному слайді.

$\checkmark$ Якщо слайди презентації супроводжують теоретичний матеріал, то їх розміщуйте поруч із текстом. Мотивуйте учнів до роботи фразами типу: «Уважно переглянь...», «Зверни увагу на ...», «Проаналізуй ...», «Виділи ...» тощо.

$\checkmark$ Плануючи перегляд фрагментів відео, ураховуйте, що його тривалість не повинна перевищувати 2-3 хвилин. Також продумайте запитання і завдання до нього, які бажано розмістити перед лінком на цей фрагмент.

$\checkmark$ Аудіофайли додавайте за умов, якщо вони містять якісний запис озвученого художнього твору (чи його фрагменту) мовою оригіналу, у виконанні автора, професійного актора, елементи радіовистави тощо. Також будуть доречними зразки сучасних інтерпретацій (реміксові композиції, аудіоколажі у форматі новочасних музичних стилів тощо). Запитання і завдання до звукового файлу розмістіть перед покликанням.

\section{4. ВИСНОВКИ ТА ПЕРСПЕКТИВИ ПОДАЛЬШИХ ДОСЛІДЖЕНЬ}

Отже, зважаючи на збільшення кількості навчальних матеріалів у відкритому доступі, проблема підготовки і проведення якісного електронного уроку в межах дистанційного навчання школярів залишається актуальною. Поруч 3 очевидними перевагами такої форми (можливість урахування індивідуальних темпів навчання кожного 3 учнів, насиченість i швидкість зворотного зв'язку 3 учителем i однокласниками та ін.) $є$ низка нагальних проблем, пов'язаних як 3 характером організації самого процесу, так і його наповненням дидактично якісним контентом.

Переконані, що науково-методичні пошуки в аспекті віддаленої співпраці вчителя й учня мають бути націлені на адаптацію до нових умов уже існуючого методичного інструментарію, можливість переосмислити його, удосконалити, а також розробити специфічні методи й прийоми навчання для застосування елементів дистанційної освіти в очному форматі. Це, у свою чергу, мотивуватиме вчителів-словесників до професійного зростання, покращить якість літературної освіти в українській школі загалом.

Певним чином, у статті ми наблизились до вирішення окреслених питань: здійснили спробу обгрунтувати авторське бачення процесу розробки електронного 
уроку із зарубіжної літератури для старшокласників й методики його реалізації на різних етапах, проілюстрували означене на прикладі упровадження елементів віддаленої співпраці педагога-куратора й учня-читача, надали рекомендації, що допоможуть учителям-словесникам значно продуктивніше використовувати дистанційний формат освіти в навчанні старшокласників зарубіжної літератури.

Проте, обсяг статті не дозволяє висвітлити всі аспекти означеної проблеми. Подальші пошуки можуть бути спрямовані на розробку е-контенту виховного потенціалу 3 навчального предмета «Зарубіжна література» щодо утвердження в старшокласників з окупованих територій ідей самовизначення на засадах українськості, пошуку алгоритмів їх повноцінної інтеграції в українське громадське середовище, так як очікуємо, що переважна більшість випускників загальноосвітніх навчальних закладів 3 дистанційною формою навчання в майбутньому вступатимуть до вітчизняних вишів. В умовах повсякдення і з урахуванням явища інформаційної війни це, на нашу думку, одне 3 першочергових завдань, що має вирішувати шкільна дистанційна освіта Донеччини.

\section{СПИСОК ВИКОРИСТАНИХ ДЖЕРЕЛ}

[1] "Концепція розвитку дистанційної освіти в Україні" [Електронний ресурс]. Доступно : http://www.osvita.org.ua/distance/pravo/00.html. Дата звернення : Лютий, 15, 2016.

[2] А. І. Богосвятська, "Використання ІКТ (інформаційно-комунікативних технологій) у процесі викладання світової літератури”, Зарубіжна література в школах Украӥни, № 2, с. 2-9, 2012.

[3] Н. Й. Волошина, "Перспективні педагогічні технології у практичній діяльності вчителя-філолога", Зарубіжна література в школах Украӥни, № 10, с. 2-3, 2006.

[4] С. Ю. Гарна, “Розвиток полікультурної особистості учня на уроках літератури засобами ІКТ”, на III Міжнародному науково-методичному семінарі Проблеми вивчення і викладання російської мови та літератури в полікультурному просторі ХХІ століття, Луцьк, 2012, с. 423-429.

[5] О. О. Дем'яненко, "Теорія і практика медіаосвіти. Світова література та медіа середовище", Всесвітня література в школах України, № 2, с. 12-14, 2014.

[6] С. О. Жила, “Сприймання літературних текстів у взаємозв'язках із суміжними видами мистецтв”, у Педагогічна освіта: теорія $і$ практика: зб. наук. праць, Вип. 3. Кам’янець-Подільський, Україна: Медобори-2006, 2009, с. 118-121.

[7] В. П. Журавлёв, “Звучащая учебная книга (Фонохрестоматия как компонент учебнометодического комплекта)”, Литература в школе, № 12, с. 20-22, 2007.

[8] Е. А. Исаева, “То, что отвлекает от книги, надо сделать союзником в создании мотивации к чтению: О современном читателе и о возможностях использования медиатекста на уроке литературы”, Русская словесность в школах Украины, № 6, с. 2-6, 2013.

[9] Ж. В. Клименко, “Тематичне оцінювання знань та вмінь учнів у запитаннях і відповідях", Всесвітня література в середніх навчальних закладах Украӥни, № 11, с. 2-5, 2002.

[10] Л. Ф. Мірошниченко, “Питання, що хвилюють усіх нас", Всесвітня література та культура $в$ навчальних закладах Украӥни, № 1, с. 15-16, 2001.

[11] Ц. Палмер, "Использование технологий в преподавании литературы" [Электронный ресурс]. Доступно: http://www.allnewteaching.com/teach-literature-with-tech/. Дата обращения : Март, 15, 2016.

[12] І. Г. Ціко, “Медіадидактичний аспект формування етнокультурної компетентності учнів 5-7 класів у процесі вивчення зарубіжної літератури”, Науковий огляд, № 5, с. 109-119, 2015.

[13] В. І. Шуляр, Електронний конструктор уроку в планувальній діяльності суб'єктів літературної освіти. Миколаїв, Україна: ОІППО, 2012, с. 84.

[14] Ю. В. Ээльмаа, С. В. Федоров, Информационные технологии на уроках литературы. Москва, Россия: Просвещение, 2012, с. 176.

[15] Міністерство освіти і науки. Наказ МОН № 466 від 25.04.2013 із змінами, внесеними згідно 3 Наказами Міністерства освіти і науки № 660 від 01.06.2013, № 761 від 14.07.2015, Положення про організацію дистанціийного навчання (затверджено.) [Електронний ресурс]. Доступно: http://zakon2.rada.gov.ua/laws/show/z0703-13. Дата звернення: Жовтень, 18, 2015. 
[16] "Концептуальні засади реформування середньої освіти “Нова українська школа””. [Електронний peсурс]. Доступно: http://mon.gov.ua/Новини\%202016/12/05/konczepcziya.pdf. Дата звернення : Грудень, 05, 2016.

[17] "E-school. Дистанційне навчання в школі" [Електронний ресурс]. Доступно: https://eschool.dn.ua/. Дата звернення : Грудень, 07, 2016.

Матеріал надійшов до редакиії 31.08.2017 p.

\title{
ОРГАНИЗАЦИЯ УРОКА ЗАРУБЕЖНОЙ ЛИТЕРАТУРЫ В СИСТЕМЕ ДИСТАНЦИОННОГО ОБУЧЕНИЯ ШКОЛЬНИКОВ
}

\author{
Гарна Светлана Юрьевна \\ заведующая отделом гуманитарного образования, старший преподаватель кафедры истории, \\ общественно-гуманитарных дисциплин и методики их преподавания \\ Донецкий областной институт последипломного образования, г. Донецк, Украина \\ ORCID ID 0000-0003-1254-9044 \\ garnasveta@ukr.net
}

\begin{abstract}
Аннотация. В статье сделан обзор последних педагогических и научно-методических наработок в контексте проблемы организации дистанционного литературного образования современных учащихся, определена методологическая база для разработки в дальнейшем методической системы использования технологий дистанционного обучения в процессе изучения зарубежной литературы старшеклассниками. Осуществлен мониторинг структуры, содержания и методического инструментария электронного урока по зарубежной литературе в системе дистанционного образования Донетчины для старшеклассников с оккупированных территорий, изучены преимущества и недостатки такого формата учебного диалога между педагогом-куратором и учащимся. Предложено авторское видение организации занятия с удаленным доступом, даны рекомендации по построению и проведению эффективного электронного урока, расширена палитра дидактического инструментария современного учителя-словесника с учетом специфики дистанционного обучения.
\end{abstract}

Ключевые слова: дистанционное образование; дистанционное обучение; литературное образование; электронный урок; методический инструментарий; кейсы материалов по зарубежной литературе.

\section{ORGANIZATION OF THE FOREIGN LITERATURE LESSON IN THE SYSTEM OF DISTANCE STUDENT'S LEARNING}

\author{
Svitlana Yu. Harna \\ Head of the Department of Humanitarian Education, Senior Lecturer of the Department of History, \\ Socio-Humanitarian Disciplines and Methods of Teaching \\ Donetsk Regional Institute of Postgraduate Pedagogical Education, Donetsk, Ukraine \\ ORCID ID 0000-0003-1254-9044 \\ garnasveta@ukr.net
}

\begin{abstract}
The article reviews the latest pedagogical and methodological works in the context of the problem of organization the distance literary education of modern students, it was determined the methodological basis for further development of methodical systems of using distance learning technologies in the process of studying foreign literature by secondary school pupils. The monitoring of the structure, content and methodical tools of the electronic lesson of foreign literature in the system of distance education in Donetsk region for secondary school pupils from the occupied territories, as well as the advantages and disadvantages of such a format of educational dialogue between the curator and the student were studied. The author's vision for the organization of classes with remote access is offered, recommendations on the construction and
\end{abstract}


implementation of an effective e-lesson were given, and the palette of didactic tools of the modern teacher-translator was extended, the specifics of distance learning was taken into account too.

Key words: distance education; distance learning; literary education; electronic lesson; methodical tools; case materials of foreign literature.

\section{REFERENCES (TRANSLATED AND TRANSLITERATED)}

[1] The concept of the development of distance education in Ukraine. [Online]. Available: http://www.osvita.org.ua/distance/pravo/00.html. Accessed on: February 15, 2016. (in Ukrainian)

[2] A. I. Bohosviatska, "Using ICT (Information and Communication Technologies) in the Process of Teaching World Literature”, Zarubizhna literatura v shkolakh Ukrainy, № 2, p. 2-9, 2012. (in Ukrainian)

[3] N. J. Voloshyna, "Perspective pedagogical technologies in the practical activity of a teacher-philologist", Zarubizhna literatura $v$ shkolakh Ukrainy, № 10, p. 2-3, 2006. (in Ukrainian)

[4] S. Iu. Harna, "Development of the multicultural personality of the student at the lessons of literature through means of ICT", at the III International Scientific and Methodological Seminar Problems of studying and teaching Russian language and literature in the multicultural space of the XXI century, Lutsk, 2012, p. 423-429. (in Ukrainian)

[5] O. O. Demianenko, "The theory and practice of media education. World literature and media environment”, Vsesvitnia literatura v shkolakh Ukrainy, № 2, p. 12-14, 2014. (in Ukrainian)

[6] S. O. Zhyla, "Perception of literary texts in interconnections with adjoining arts", in Pedahohichna osvita: teoriia i praktyka: zb. nauk. prats, Vyp. 3. Kamianets-Podilskyi, Ukraina: Medobory-2006, 2009, p. 118-121. (in Ukrainian)

[7] V. P. Zhuravlov, "Sound educational book (Phonochrestomathy as a component of educational and methodical set)", Literatura $v$ shkole, № 12, p. 20-22, 2007. (in Russian)

[8] E. A. Isaeva, "What distracts from the book should be made an ally in creating a motivation for reading: On the modern reader and on the possibilities of using media text in the literature class", Russkaja slovesnost' v shkolah Ukrainy, № 6, p. 2-6, 2013. (in Russian)

[9] Zh. V. Klymenko, "Thematic evaluation of pupils' knowledge and abilities in questions and answers", Vsesvitnia literatura $v$ serednikh navchalnykh zakladakh Ukrainy, № 11, p. 2-5, 2002. (in Ukrainian)

[10] L. F. Miroshnychenko, "Questions that concern us all", Vsesvitnia literatura ta kultura $v$ navchalnykh zakladakh Ukrainy, № 1, p. 15-16, 2001. (in Ukrainian)

[11] Ts. Palmer, The use of technology in the teaching of literature [Online]. Available: http://www.allnewteaching.com/teach-literature-with-tech/. Accessed on: March 15, 2016. (in Ukrainian)

[12] I. H. Tsiko, "The media-didactic aspect of the formation of ethnocultural competence of students 5-7 classes in the process of studying foreign literature”, Naukovyi ohliad, № 5, p. 109-119, 2015. (in Ukrainian)

[13] V. I. Shuliar, Electronic designer lesson in the planning activities of persons of literary education. Mykolaiv, Ukraina: OIPPO, 2012, p. 84. (in Ukrainian)

[14] Iu. V. Eelmaa, S. V. Fedorov, Information technology at literature lessons. Moskva, Rossija: Prosveshhenie, 2012, p. 176. (in Russian)

[15] Ministerstvo osvity i nauky. Nakaz MON № 466 vid 25.04.2013 iz zminamy, vnesenymy zghidno $z$ Nakazamy Ministerstva osvity $i$ nauky № 660 vid 01.06.2013, № 761 vid 14.07.2015, Polozhennia pro orhanizatsiiu dystantsiinoho navchannia (zatverdzheno) [Online]. Available: http://zakon2.rada.gov.ua/laws/show/z0703-13. Accessed on: October 18, 2015. (in Ukrainian)

[16] The Conceptual Principles of Reforming Secondary Education "New Ukrainian School". [Online]. Available: http://mon.gov.ua/Novyny\%202016/12/05/konczepcziya.pdf. Accessed on: December 05, 2016. (in Ukrainian)

[17] E-school. Distance learning at school. [Online]. Available: https://eschool.dn.ua/. Accessed on: December 07, 2016. (in Ukrainian)

\section{(c) BY-NC-SA}

This work is licensed under Creative Commons Attribution-NonCommercial-ShareAlike 4.0 International License. 